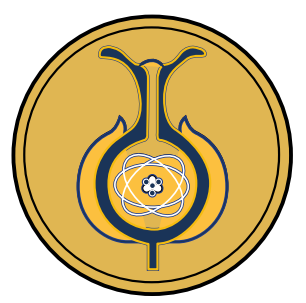

\title{
Nitrates Evaluation in the National Térraba-Sierpe Wetland
}

\author{
Evaluación de nitratos en el Humedal Nacional Térraba-Sierpe \\ Avaliação de nitrato na Zona Úmida Nacional Térraba-Sierpe
}

\section{Laura Hernández-Alpízar'1, Jesús Mora-Molina ${ }^{1}$}

Received: Dec/2/2020 • Accepted: Set/16/2021 • Published: Jan/31/2022

\section{Abstract (1D)}

This research aimed to describe, spatially and temporally, the concentrations of nitrates in correlation with anthropogenic activities surrounding the Sierpe River that crosses the National Térraba-Sierpe Wetland (HNTS). Although territorially protected by Costa Rican legislation, this wetland is surrounded by intense agricultural activity. In 2018, monthly monitoring of $\mathrm{pH}$, nitrates, and dissolved oxygen was carried out in fourteen points of the river. A baseline around $5 \mathrm{mg} \mathrm{NO}_{3} / \mathrm{L}$ was obtained in periods without agricultural activities and peaks up to $20 \mathrm{mg} \mathrm{NO}_{3}^{-} / \mathrm{L}$ after fertilization activities. Correspondingly, a decrease in dissolved oxygen and $\mathrm{pH}$ was observed on days of high agricultural activity. In the months following fertilization, accelerated growth of aquatic plants and a general deterioration in mangrove reproduction were observed by collaborators of the HNTS management and surveillance program. Nevertheless, when high nitrates concentration in agricultural areas are observed, their decline is also observed in the direction of the river's flow until it reaches its mouth. This facts shows the still active function of the wetland and its importance in the processing of nitrates. To regulate activities not only in the territorial limit but also in the limits of the water system surrounding the HNTS is recommended to protect this ecosystem function.

Keywords: nitrates, wetlands, sustainable agriculture, ecological impacts, National Térraba-Sierpe Wetland

\section{Resumen (10)}

El objetivo de esta investigación fue describir espacial y temporalmente las concentraciones de nitratos en correlación con las actividades antropogénicas que rodean el río Sierpe que atraviesa el Humedal Nacional Térraba-Sierpe (HNTS). Aunque protegido territorialmente por la legislación costarricense, este humedal está rodeado por una intensa actividad agrícola. En el 2018 se realizó un monitoreo mensual de $\mathrm{pH}$, nitratos y oxígeno disuelto (OD) en catorce puntos del río. Se obtuvo una línea base alrededor de 5 $\mathrm{mg} \mathrm{NO}_{3} / \mathrm{L}$ en períodos sin actividades agrícolas y picos hasta de $20 \mathrm{mg} \mathrm{NO}_{3} / \mathrm{L}$ después de las actividades de fertilización. Correspondientemente se observó disminución de OD y pH en los días de alta actividad agrícola. En los meses posteriores a la fertilización, los colaboradores del programa de manejo y vigilancia del HNTS observan un crecimiento acelerado de plantas acuáticas y un deterioro general en la reproducción

Laura Hernández-Alpízar, \lahernandez@itcr.ac.cr, (i) https://orcid.org/0000-0002-9193-8429

Jesús Mora-Molina, \jmora@itcr.ac.cr, (D) https://orcid.org/0000-0002-2309-940

1 Chemistry Department, Technological Institute of Costa Rica. Cartago, Costa Rica. 
del manglar. Sin embargo, cuando se observa una alta concentración de nitratos en áreas agrícolas, también se observa su declive en la dirección del flujo del río hasta su desembocadura. Este hecho muestra la función aún activa del humedal y su importancia en el procesamiento de nitratos. Se recomienda regular las actividades no solo en el límite territorial sino también en los límites del sistema hídrico circundante al HNTS para proteger esta función ecosistémica.

Palabras clave: nitratos; humedal; agricultura sostenible; impactos ecológicos; Humedal Nacional Térraba-Sierpe.

\section{Resumo}

Esta pesquisa teve como objetivo descrever espacial e temporariamente as concentrações de nitrato em correlação com as atividades antropogênicas que cercam o rio Sierpe. Este rio atravessa a Zona Úmida Nacional Térraba-Sierpe (HNTS) que, embora territorialmente protegida pela legislação costarriquenha, é cercada por intensa atividade agrícola. Em 2018, foi realizado um monitoramento mensal de $\mathrm{pH}$, nitratos e oxigênio dissolvido em catorze pontos do rio, onde foi obtida uma linha de base em torno de $5 \mathrm{mg}$ $\mathrm{NO}_{3} / \mathrm{L}$ em períodos sem atividades agrícolas e picos de até $20 \mathrm{mg} \mathrm{NO} / \mathrm{L}$ após eventos de fertilização. Correspondentemente, observou-se a diminuição do oxigênio dissolvido e do pH nos dias de alta atividade agrícola. Nos meses seguintes à fertilização, os colaboradores do programa de gestão e vigilância do HNTS observam um crescimento acelerado de plantas aquáticas e uma deterioração geral na reprodução de manguezais. No entanto, a concentração de nitratos diminui sistematicamente na direção do fluxo do rio até chegar à foz, o que mostra a função ainda ativa da zona úmida e sua importância no processamento de nitratos. A fim de proteger essa função ecossistêmica, recomenda-se a necessidade de regulação das atividades, não apenas dentro do limite territorial, mas também dos limites do sistema de água em torno do HNTS.

Palavras-chave: nitratos; zonas úmidas; agricultura sustentável; impactos ecológicos; Zona Úmida Nacional Térraba-Sierpe.

\section{Introduction}

The exponential growth of world population, agriculture and intensive fertilization are related to the imbalance of global nitrogen processing (Galloway et al., 2008; Sutton et al., 2012). Before the industrial generation of fertilizers, nitrogen was naturally incorporated into the soil and the oceans by atmospheric or biological fixation, afterward recycled through bacterial denitrification (Olivares, Bedmar, \& Sanjuán, 2013). Currently, about half of global nitrogen fixation occurs on land, and at least half of this fixation has its origin in intensive fertilization (Fowler et al., 2013). Overused reactive nitrogen forms (nitrate ion, nitrogen oxides, ammonia, and ammonium species) flow from application in agricultural lands towards watersheds or to the atmosphere, without healthy bioprocessing for the planet. (Devol, 2015). An excessive supply of nutrients to a water body causes abnormal growth of microorganisms and aquatic plants that reduce the penetration of radiation and consume dissolved oxygen 
(hypoxia). Aquatic species show diverse tolerance to moderate hypoxic conditions (less than $4 \mathrm{mgO}_{2}$ dissL ${ }^{-1}$ ) (Gilmore, Doubleday, \& Gillanders, 2019; Johnson, Powers, Senne, \& Park, 2009). In Latin America, the rate of nitrogen species entry into ecosystems is greater than in developed countries and threatens biodiversity hotspots on the continent (Austin et al., 2013).

Oceans denitrify at a higher rate and magnitude than land areas; notwithstanding, the efficiency depends on the oxygen supply (Canfield, Glazer, \& Falkowski, 2010; Devol, 2015). The continuous nutrients reception causes oxygen depletion and also acidification (Fennel \& Testa, 2019). Wetlands remove excess nutrients and decontaminate the water resource before entering the oceans (Fisher \& Acreman, 2004; Hansen, Dolph, \& Finlay, 2016). Nevertheless, wetlands are drained and used for monocultures that use intensive fertilization and distress the important ecological services they offer (Audet et al., 2015; Pirker, Mosnier, Kraxner, Havlík, \& Obersteiner, 2016; Srinivas \& Koh, 2016; Walsh et al., 2016).

Oil palm is a good example of an intensive crop that develops around the world, threatening forest and tropical wetlands (Dislich et al., 2017; Khatun, Reza, Moniruzzaman, \& Yaakob, 2017). In Costa Rica, a combination of livestock, rice and intensive oil palm cultivation has develop and expanded in a territory located around a wetland area protected by national laws, the National Térraba-Sierpe Wetland (HNTS). This wetland is located in the Osa Peninsula, Costa Rica, and its ecological cleaning functions could be affected by intense anthropogenic activity (Gallmetzer \& Schulze, 2015; Hernández-Alpízar, Mora-Molina, \& Coy-Herrera, 2020; Taylor et al., 2018; Weintraub et al., 2018).
The Sierpe River crosses the HNTS and receives the agricultural effluents. Monthly monitoring was established at selected points of the river to analyze nitrates, dissolved oxygen (DO) and $\mathrm{pH}$, as well as taking observations of the site in collaboration with the HNTS managers. The objective of this research was to describe, spatially and temporally, the nitrate concentrations in the Sierpe River associated with observations of the anthropogenic activities that surround it.

\section{Method}

A sampling strategy was designed in operational congruence with the "Fish Surveillance Program" included in the HNTS management plan. The sampling was stratified (random selection of sampling points) and BACI type, which is applied when the type of impact that may be affecting a wetland is known (eutrophication, change in species population). The use of physicochemical indicators with the observation of species and ecological impacts is a recommendation described in the EPA method for the design of wetland studies "Methods for evaluating Wetland Condition. \#4 Study Design for Monitoring Wetlands" (U.S. EPA, 2002).

The fourteen sampling locations were registered using two GPS systems, MAP64SC (Figure 1). Monthly monitoring covered variations in weather conditions, agricultural, and urban activities during 2018. Agricultural patterns were visualized using the Google Earth Pro platform, 2020, version 7.3.3.7699 (64-bit). The anthropogenic activities were detailed with the park managers. 


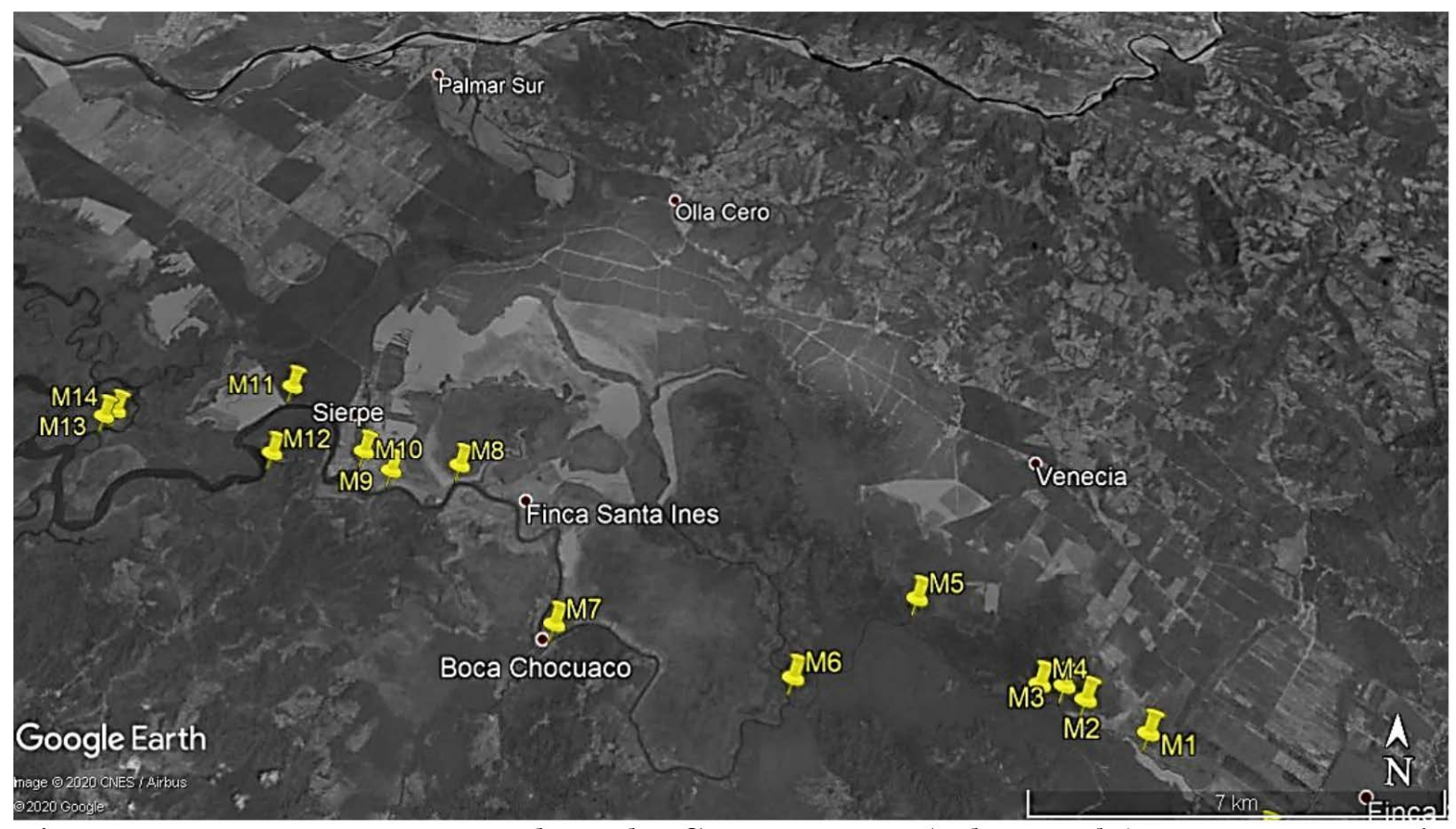

Figure 1. Monitoring network in the Sierpe River (7 km scale). Map generated with Google Earth Pro, 2020, version 7.3.3.7699 (64-bit). Build Date: Thursday, May 7, 2020, 12:27:47 AM UTC. Last access: 6/20/2020 (anthropogenic activity is maintained as 2018).

DO was measured in situ with a fluorometer, NEOFOX-GT from Ocean Optics. Conductivity and $\mathrm{pH}$ are also measured on site with Metrohm brand handheld device (model 914) and a fastresponse $\mathrm{pH}$ electrode (iAquatrode). HDPE amber bottles $(250 \mathrm{~mL})$ were used to uptake water samples at a depth of $30 \mathrm{~cm}$. The samples were transported and refrigerated the same day to the laboratory and analyzed the following days, as soon as possible and within a week.
For nitrates analysis, a UVFIA spectroscopic set up described in CR20180476A were applied (HernándezAlpízar \& Coy-Herrera, 2019). The analytical system employs the miniature spectrometer Maya 2000-Pro (Ocean Optics), UV absorbance measurements were carried out at $223.96 \mathrm{~nm}$

The connectivity of the sampled hydrological flow path is continuous. The following description of the sampling sites (Table 1) is obtained from the visits, the information provided by the HNTS managers, and the visual examination on the Google Earth map (Figure 1). 


\section{Table 1}

Description of the sampling sites in the Sierpe River monitoring network in 2018.

\begin{tabular}{|c|c|c|}
\hline $\begin{array}{l}\text { Sampling } \\
\text { Site }\end{array}$ & $\begin{array}{l}\text { Anthropogenic con- } \\
\text { tributions }\end{array}$ & Description \\
\hline M1 & Agricultural & Oil palm farms at short distance/Shallow low-flow waters \\
\hline M2 & Agricultural & Oil palm farms at short distance/Shallow low-flow waters \\
\hline M3 & Agricultural & Oil palm /Large cultivated areas/entrance to the Porvenir lagoon. \\
\hline M4 & Agricultural & $\begin{array}{l}\text { Oil palm /Large cultivated areas at medium distance from sample } \\
\text { collection site }\end{array}$ \\
\hline M5 & Agricultural & Rice/Oil palm at short distance from sample collection $(<5 \mathrm{Km})$ \\
\hline M6 & Agricultural & Oil palm /Large cultivated areas at medium distance $(<10 \mathrm{Km})$ \\
\hline M7 & Agricultural & Oil palm small crops/ Collection point on the cost side of the river \\
\hline M8 & Agricultural & Rice/Oil palm at short distance from sample collection site \\
\hline M9 & Agricultural/Urban & Rice/Oil palm at short distance from sample collection site \\
\hline M10 & Agricultural/Urban & Urban and Oil palm /large cultivated areas at short distance \\
\hline M11 & Agricultural & Oil palm /large cultivated areas at short distance \\
\hline M12 & Agricultural & Oil palm /large cultivated areas at short distance \\
\hline M13 & None & Sampling site at shallow waters of the river mouth \\
\hline M14 & None & Sampling site at shallow waters of the river mouth \\
\hline
\end{tabular}

Note: derived from research.

\section{Analysis and results}

Table 2 provides the georeferenced location of the sampling sites and the average $\mathrm{pH}$ of each collection site throughout the year. Crop fertilization is generally applied in transition periods from dry to rainy season. The $\mathrm{pH}$ minima correlate well with the type of water flow and the spatial and temporal distribution of anthropogenic activities. After the application of fertilizers (from the end of April to June), a drop in $\mathrm{pH}$ from M2 to M8 was observed, the sites with agricultural effluents. From M9 to M11 (mixed urban-agricultural activities) and from M12 to
M14 (the shallowest water in the network), the acidity can be interpreted as a result of the nitrification process (conversion of ammonium ion to nitrate ion) occurring in the upper layer of shallow waters, with a change from equilibrium to hypoxic conditions in deep layers. Additional acidification can develop from aquatic plant nutrition and benthic denitrification in sediments, limited by the availability of dissolved organic matter that can also be supplied by absorption of atmospheric $\mathrm{CO}_{2}$ (Devol, 2015; Fennel \& Testa, 2019; Taylor \& Townsend, 2010). 
Table 2

Location and $\mathrm{pH}$ of the sampling sites in the Sierpe River monitoring network (2018.)

\begin{tabular}{|c|c|c|c|c|c|}
\hline $\begin{array}{l}\text { Sampling } \\
\text { site }\end{array}$ & Latitude/length & $\begin{array}{l}\text { pH (aver- } \\
\text { age) }\end{array}$ & $\operatorname{Min} *$ & Max & $\begin{array}{l}\text { Standard } \\
\text { deviation }\end{array}$ \\
\hline M1 & $8^{\circ} 48^{\prime} 55.19^{\prime \prime} \mathrm{N} / 83^{\circ} 20^{\prime} 20.78^{\prime \prime} \mathrm{O}$ & 7.30 & 6.48 & 7.90 & 0.46 \\
\hline M2 & $8^{\circ} 49^{\prime} 12.84^{\prime \prime} \mathrm{N} / 83^{\circ} 20^{\prime} 53.94 ” O$ & 6.66 & 6.10 & 7.20 & 0.34 \\
\hline M3 & $8^{\circ} 49^{\prime} 20.46^{\prime \prime} \mathrm{N} / 83^{\circ} 21^{\prime} 5.10^{\prime \prime} \mathrm{O}$ & 6.69 & 6.45 & 6.90 & 0.16 \\
\hline M4 & $8^{\circ} 49^{\prime} 20.82^{\prime} \mathrm{N} / 83^{\circ} 21^{\prime} 19.08^{\prime \prime O}$ & 6.83 & 6.37 & 7.27 & 0.33 \\
\hline M5 & $8^{\circ} 50^{\prime} 9.42^{\prime \prime} \mathrm{N} / 83^{\circ} 22^{\prime} 26.70^{\prime \prime} \mathrm{O}$ & 6.75 & 6.26 & 7.12 & 0.28 \\
\hline M6 & $8^{\circ} 49^{\prime} 20.82^{\prime} \mathrm{N} / 83^{\circ} 23^{\prime} 39.30^{\prime \prime} \mathrm{O}$ & 6.78 & 6.30 & 7.15 & 0.28 \\
\hline M7 & $8^{\circ} 49^{\prime} 48.24^{\prime \prime} \mathrm{N} / 83^{\circ} 25^{\prime} 58.26^{\prime \prime} \mathrm{O}$ & 6.76 & 6.24 & 7.28 & 0.33 \\
\hline M8 & $8^{\circ} 51^{\prime} 27.30^{\prime \prime} \mathrm{N} / 83^{\circ} 27^{\prime} 6.42^{\prime \prime} \mathrm{O}$ & 6.81 & 6.40 & 7.20 & 0.30 \\
\hline M9 & $8^{\circ} 51^{\prime} 22.50^{\prime \prime} \mathrm{N} / 83^{\circ} 27^{\prime} 48.30^{\prime \prime} \mathrm{O}$ & 6.96 & 6.50 & 7.45 & 0.32 \\
\hline M10 & $8^{\circ} 51^{\prime} 34.98^{\prime \prime} \mathrm{N} / 83^{\circ} 28^{\prime} 7.32^{\prime \prime O}$ & 6.79 & 6.42 & 7.15 & 0.25 \\
\hline M11 & $8^{\circ} 52^{\prime} 19.26^{\prime \prime} \mathrm{N} / 83^{\circ} 29^{\prime} 0.66^{\prime \prime} \mathrm{O}$ & 6.62 & 5.28 & 7.22 & 0.56 \\
\hline M12 & $8^{\circ} 51^{\prime} 32.46^{\prime \prime} \mathrm{N} / 83^{\circ} 29^{\prime} 4.32^{\prime \prime} \mathrm{O}$ & 6.70 & 6.32 & 7.20 & 0.29 \\
\hline M13 & $8^{\circ} 51^{\prime} 55.08^{\prime \prime} \mathrm{N} / 83^{\circ} 30^{\prime} 55.86^{\prime \prime}$ & 6.63 & 6.10 & 7.08 & 0.30 \\
\hline M14 & $8^{\circ} 51^{\prime} 58.98^{\prime \prime} \mathrm{N} / 83^{\circ} 30^{\prime} 49.26^{\prime \prime} \mathrm{O}$ & 6.66 & 6.30 & 7.10 & 0.30 \\
\hline
\end{tabular}

* Minimum observed between late April and June.

Note: derived from research.

The lowest DO values were found in the sampling sites M2 to M8 (Table 3), between the months of April and June, that is, during the customary period of fertilizer application that takes place during the transition from the dry to rainy season. DO minimums correspond closely to levels considered as moderate and intense hypoxia. This is in line with the high proliferation of aquatic vegetation observed in the river surface in the same period, particularly for M2 to M4. These collection sites have low flow conditions and vegetation sometimes prevent navigation. Throughout the year, DO levels increased downstream M8 and at the end of the rainy season, DO levels increased for the entire sampling network. 
Table 3

Dissolved oxygen concentration $\left(m g L^{-1}\right)$ in the Sierpe River monitoring network in 2018.

\begin{tabular}{lllll}
$\begin{array}{l}\text { Sam- } \\
\text { pling } \\
\text { site }\end{array}$ & Mean & Min* & Max & $\begin{array}{l}\text { Standard } \\
\text { Devia- } \\
\text { tion }\end{array}$ \\
\hline M1 & 9.30 & 8.01 & 10.4 & 1.0 \\
M2 & 5.04 & 1.72 & 6.97 & 2.1 \\
\hline M3 & 4.98 & 1.60 & 7.80 & 2.3 \\
M4 & 5.30 & 1.67 & 7.93 & 2.5 \\
\hline M5 & 6.30 & 3.51 & 8.97 & 2.4 \\
M6 & 6.84 & 4.72 & 9.74 & 2.1 \\
M7 & 7.13 & 4.98 & 9.35 & 1.8 \\
M8 & 7.31 & 5.15 & 9.85 & 2.0 \\
M9 & 7.56 & 5.23 & 9.62 & 1.7 \\
M10 & 7.43 & 5.50 & 9.82 & 1.6 \\
M11 & 7.42 & 5.44 & 10.3 & 1.7 \\
\hline M12 & 7.17 & 5.45 & 8.64 & 1.3 \\
M13 & 7.77 & 6.07 & 10.0 & 1.5 \\
M14 & 7.59 & 5.90 & 9.72 & 1.6 \\
\hline & & & & \\
\hline
\end{tabular}

* Minimum observed between May and July. Note: derived from research.

Nitrate concentration varies widely throughout the year (Table 4). Maximum values occurred during fertilizer application in the months of April, May and June, particularly from M2 to M8 (agricultural areas) and M9-M10 which receive discharges from mixed urban-agricultural activities. These results indicated that an external event such as fertilization effectively changed the nitrate concentration. These sampling sites showed general averages in the upper limit of those reported in the literature (around $5 \mathrm{mgL}^{-1}$ ) for surface waters impacted by agriculture (Taylor \& Townsend, 2010). On the days of fertilization and transition from the dry to the rainy season, the concentration of nitrates in the Sierpe River occurred up to a maximum of 20.26 $\mathrm{mgL}^{-1}$ in $\mathrm{M} 4$. While in a nearby conserved natural region, only brief periods had been detected in which nitrate concentrations increased slightly during the peak of the dry season, probably due to nitrification in the soil and low flow rates (Taylor et al., 2018; Weintraub et al., 2018).

\section{Table 4}

Nitrate concentration $\left(m g L^{-1}\right)$ in the Sierpe River monitoring network in 2018.

\begin{tabular}{|c|c|c|c|c|}
\hline $\begin{array}{l}\text { Sam- } \\
\text { pling } \\
\text { Site }\end{array}$ & Mean & Min* & Max** & $\begin{array}{l}\text { Stan- } \\
\text { dard } \\
\text { Devia- } \\
\text { tion }\end{array}$ \\
\hline M1 & 1.86 & 0.79 & 4.76 & 1.20 \\
\hline M2 & 4.57 & 2.11 & 9.85 & 2.06 \\
\hline M3 & 6.29 & 2.44 & 10.22 & 2.91 \\
\hline M4 & 6.74 & 2.72 & $20.26 * * *$ & 5.25 \\
\hline M5 & 6.29 & 2.32 & 12.46 & 2.98 \\
\hline M6 & 7.05 & 3.52 & 14.98 & 3.40 \\
\hline M7 & 6.12 & 1.94 & 13.91 & 3.65 \\
\hline M8 & 7.32 & 4.17 & 11.33 & 2.48 \\
\hline M9 & 7.53 & 3.76 & 16.29 & 4.21 \\
\hline M10 & 6.24 & 1.47 & 17.83 & 4.32 \\
\hline M11 & 4.81 & 2.41 & 8.07 & 1.74 \\
\hline M12 & 6.01 & 3.69 & 8.02 & 1.68 \\
\hline M13 & 5.77 & 2.98 & 8.03 & 1.49 \\
\hline M14 & 5.04 & 2.60 & 6.78 & 1.19 \\
\hline
\end{tabular}

* Minima observed between February-March and December; ** Maxima observed between April-June; $* * * 27 / 4 / 2018$.

Note: derived from research. 
Finally, the annual distribution of nitrate concentration in selected sampling sites was observed as indicated in Figure 2. It can be observed that nitrate concentration values along the Sierpe River fluctuate and decreased until reaching a minimum at the mouth. This is an expected effect of nitrate dinamics in wetlands (Fisher \& Acreman, 2004; Hansen et al., 2016).

The sampling points M4 and M10 with intense agricultural and nearby urban anthropogenic activity showed the most intense increase in nitrate concentration. With the rains in late April, fertilization of crops began, and the concentration of nitrates increased notably. After the rainy season in October, a second fertilization period was performed, and another increase was observed. Nevertheless, this increase was less pronounced, probably due to the dilution effect of the abundant flows resulting from the rainy season.

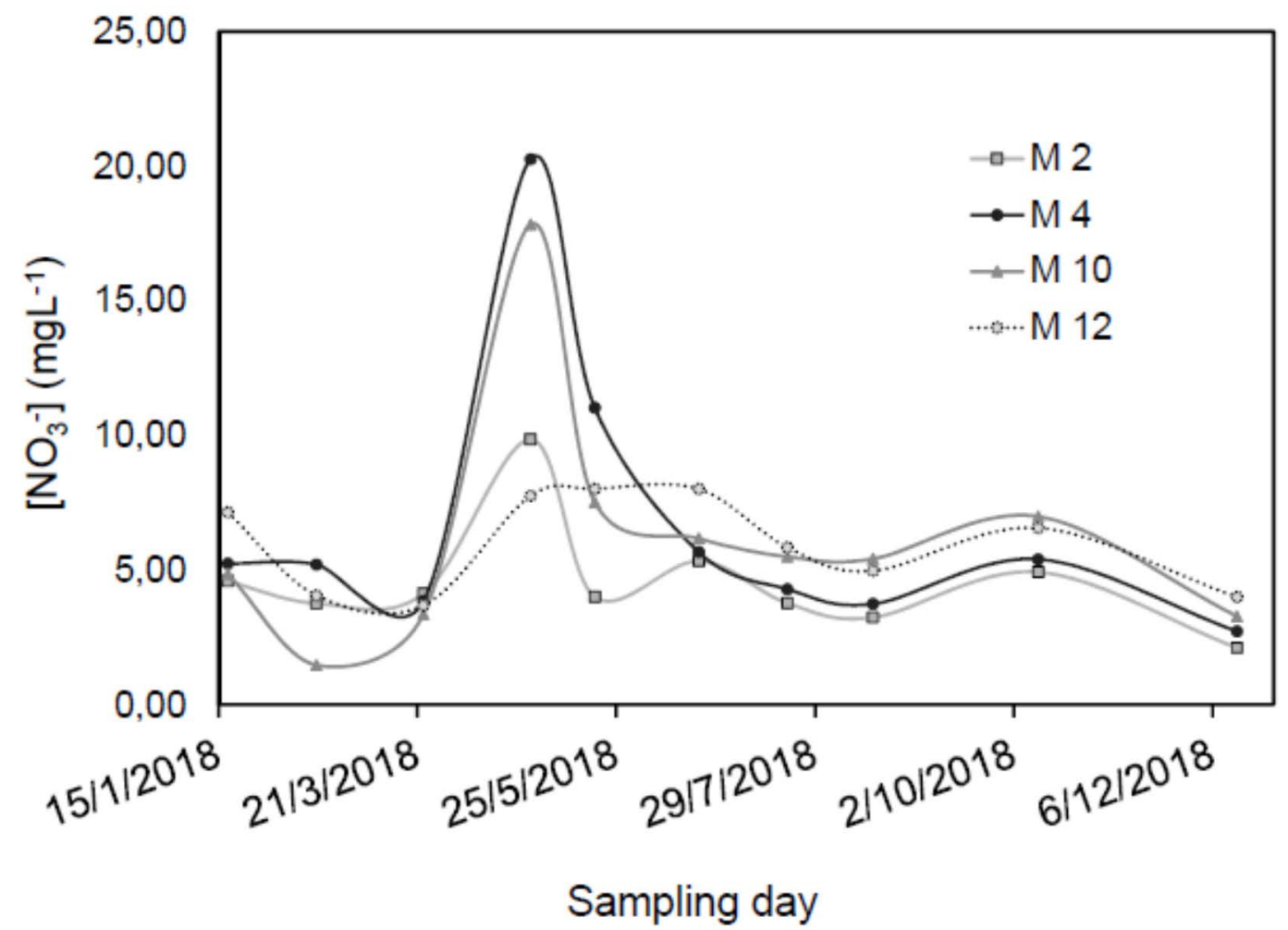

Figure 2. Nitrate concentration (mgL1-) at the beginning of the Sierpe River (M2), at receiving points for agricultural activities (M4) and agricultural and urban activities (M10), and at the end of the river (M12).

Note: derived from research. 


\section{Conclusions}

This research concluded that fertilization activities are directly related to the temporary increase in nitrate concentrations in the Sierpe River. The seasonal increase in aquatic vegetation observed by park managers could be a sign of present and future changes in the wetland ecosystem due to excess nutrients entering the water system.

Intensive agricultural production and nutrient cycling imbalance have negative effects on biological diversity and the life-sustaining functions of ecosystems. Its continuous loss is today among the main problems of the planet. Considering the findings of this work, it is evident that the protection of natural systems such as the National Térraba-Sierpe Wetland must be carried out beyond the limits of its territory, extending towards the water system in which they are located. In this framework, it is reasonable and recommended to create regulations for fertilizers addition or buffer zones to avoid the loss of invaluable resources for our own lives over time with the continuity of impacts.

\section{Acknowledgments}

The authors would like to thank the Vice Presidency for Research and Extension (VIE) of the Technological Institute of Costa Rica for financial and advisory support. We also thank the Center for Research in Environmental Protection (CIPA) and the Center for Research and Chemical and Microbiological Services (CEQIATEC) for laboratory support.

A special acknowledgment is extended to the HNTS park administration for showing interest in the research and granting permission to conduct it. The acknowledgment also goes to those responsible for the surveillance program for the valuable help provided.

\section{Conflict of Interest}

The authors declare no competing interests.

\section{Author contribution statement}

All the authors declare that the final version of this paper was read and approved. The total contribution percentage for the conceptualization, preparation, and correction of this paper was as follows: LHA $80 \%$ and JMM $20 \%$.

\section{Data availability statement}

The data supporting the results of this study will be made available by the corresponding author, [LHA], upon reasonable request.

\section{References}

Audet, J., Baattrup-Pedersen, A., Andersen, H. E., Andersen, P. M., Hoffmann, C. C., Kjaergaard, C., \& Kronvang, B. (2015). Environmental controls of plant species richness in riparian wetlands: Implications for restoration. Basic and Applied Ecology, 16(6), 480-489. https://doi.org/10.1016/j.baae.2015.04.013

Austin, A. T., Bustamante, M. M. C., Nardoto, G. B., Mitre, S. K., Pérez, T., Ometto, J. P. H. B., ... Martinelli, L. A. (2013). Latin America's Nitrogen Challenge. Science, 340(6129), 149. https://doi.org/10.1126/science.1231679

Canfield, D. E., Glazer, A. N., \& Falkowski, P. G. (2010). REVIEW The Evolution and Future of Earth's Nitrogen Cycle. Science, 330, 192 196. https://doi.org/10.1126/science. 1186120 
Devol, A. H. (2015). Denitrification, Anammox, and N 2 Production in Marine Sediments. Annual Review of Marine Science, 7(1), 403-423. https://doi.org/10.1146/ annurev-marine-010213-135040

Dislich, C., Keyel, A. C., Salecker, J., Kisel, Y., Meyer, K. M., Auliya, M., ... Wiegand, K. (2017). A review of the ecosystem functions in oil palm plantations, using forests as a reference system. Biological Reviews, 92(3), 1539-1569. https://doi.org/10.1111/ brv. 12295

Fennel, K., \& Testa, J. M. (2019). Biogeochemical Controls on Coastal Hypoxia. Annual Review of Marine Science, 11(1), 105-130. https://doi. org/10.1146/annurev-marine-010318-095138

Fisher, J., \& Acreman, M. C. (2004). Wetland nutrient removal: a review of the Wetland nutrient removal: a review of the evidence. Hydrology and Earch System Sciences, 8(4), 673-685. https://doi.org/10.5194/hess-8-673-2004

Fowler, D., Coyle, M., Skiba, U., Sutton, M. A., Cape, J. N., Reis, S., Sheppard, L.J., Jenkins, A., Grizzetti, B. Galloway, J. N. Vitousek, P., Leach, A. Bouwman, A.F., Butterbach-Bahi, K., Dentener, F., Stevenson, D., Amann, M. \& Voss, M. (2013). The global nitrogen cycle in the twenty-first century. Philosophical Transactions of the Royal Society B: Biological Sciences, 368(1621), 20130164. https://doi. org/10.1098/rstb.2013.0164

Gallmetzer, N., \& Schulze, C. H. (2015). Impact of oil palm agriculture on understory amphibians and reptiles: A Mesoamerican perspective. Global Ecology and Conservation, 4, 95-109. https://doi.org/10.1016/j. gecco.2015.05.008

Galloway, J. N., Townsend, A. R., Erisman, J. W., Bekunda, M., Cai, Z., Freney, J. R., ... Sutton, M. A. (2008). Transformation of the nitrogen cycle: Recent trends, questions, and potential solutions. Science, 320(5878), 889-892. https://doi.org/10.1126/science. 1136674

Gilmore, K. L., Doubleday, Z. A., \& Gillanders, B. M. (2019). Prolonged exposure to low oxygen improves hypoxia tolerance in a freshwater fish. Conservation Physiology, 7(1), 1-10. https://doi.org/10.1093/conphys/coz058

Hansen, A. T., Dolph, C. L., \& Finlay, J. C. (2016). Do wetlands enhance downstream denitrification in agricultural landscapes? Ecosphere, 7(10). https://doi.org/10.1002/ecs2.1516
Hernández-Alpízar, L., Mora-Molina, J., \& Coy-Herrera, R. (2020). Monitoreo de nitratos en los drenajes de palma aceitera (Elaeis guineensis): una herramienta para la sostenibilidad del cultivo, UNED Research Journal, 12(1). Retrieved from https://revistas.uned.ac.cr/ index.php/cuadernos/article/view/2807/3569

Hernández-Alpízar, L. \& Coy-Herrera, R. (2019). Dispositivo y método de calibración interpolativo en análisis cuantitativo de flujo continuo. CR20180476 (A). https://worldwide. espacenet.com/searchResults?submitted $=$ true $\&$ locale $=$ en_EP\&DB $=$ EPODOC $\& S T=$. singleline \&query $=\mathrm{CR} 20180476 \&$ Submit $=$ Search

Johnson, M. W., Powers, S. P., Senne, J., \& Park, K. (2009). Assessing in Situ Tolerances of Eastern Oysters (Crassostrea virginica) Under Moderate Hypoxic Regimes: Implications for Restoration. Journal of Shellfish Research, 28(2), 185-192. https://doi. org/10.2983/035.028.0202

Khatun, R., Reza, M. I. H., Moniruzzaman, M., \& Yaakob, Z. (2017). Sustainable oil palm industry: The possibilities. Renewable and Sustainable Energy Reviews, 76(August 2016), 608-619. https://doi.org/10.1016/j. rser.2017.03.077

Olivares, J., Bedmar, E. J., \& Sanjuán, J. (2013). Biological Nitrogen Fixation in the Context of Global Change. Molecular Plant-Microbe Interactions, 26(5), 486-494. https://doi. org/10.1094/MPMI-12-12-0293-CR

U.S. EPA. (2002). Methods for Evaluating Wetland Condition: Study Design for MonitoringWetlands. Office of Water, U.S. Environmental Protection Agency, Washington, DC.EPA822-R-02-015. Retrieved from https://www. epa.gov/sites/production/files/documents/ wetlands_4studydesign.pdf

Pirker, J., Mosnier, A., Kraxner, F., Havlík, P., \& Obersteiner, M. (2016). What are the limits to oil palm expansion? Global Environmental Change, 40, 73-81. https://doi.org/10.1016/j. gloenvcha.2016.06.007

Srinivas, A., \& Koh, L. P. (2016). Oil palm expansion drives avifaunal decline in the Pucallpa region of Peruvian Amazonia. Global Ecology and Conservation, 7, 183-200. https://doi. org/10.1016/j.gecco.2016.06.005 
Sutton, M. A., Reis, S., Billen, G., Cellier, P., Erisman, J. W., Mosier, A. R., ... Skiba, U. (2012). Preface: "'Nitrogen \& global change"." Biogeosciences, 9(5), 1691-1693. https://doi. org/10.5194/bg-9-1691-2012

Taylor, P. G., \& Townsend, A. R. (2010). Stoichiometric control of organic carbon-nitrate relationships from soils to the sea. $\mathrm{Na}$ ture, 464(7292), 1178-1181. https://doi. org/10.1038/nature08985

Taylor, P. G., Wieder, W. R., Weintraub, S., Cohen, S., Cory, C., Townsend, A. R., ... Townsend, A. R. (2018). Organic forms dominate hydrologic nitrogen export from a lowland tropical watershed Published by: Wiley on behalf of the Ecological Society of America Stable URL: http://www.jstor.org/stable/43495008 Organic forms dominate hydrologie nitrogen export fro, 96(5), 1229-1241.
Walsh, R. P. D., Nainar, A., Bidin, K., Higton, S. Annammala, K. V, Blake, W., ... Hanapi, J. (2016). Hydrogeomorphological and water quality impacts of oil palm conversion and logging in Sabah, Malaysian Borneo: a multi-catchment approach. Geophysical Research Abstracts, 18(4), EGU2016-18195. http:// meetingorganizer.copernicus.org/EGU2016/ EGU2016-18195.pdf

Weintraub, S. R., Taylor, P. G., Porder, S., Cleveland, C. C., Asner, G. P., Townsend, A. R., ... Townsend, A. R. (2018). Topographic controls on soil nitrogen availability in a lowland tropical forest. Wiley on behalf of the Ecological Society of America Stable http://www. jstor.org/stable/43495119 Topographic controls on soil nitrogen availability in a 1, 96(6), 1561-1574.

\section{(9) $(1) \Theta$}

$\underline{\text { Uniciencia is protected by Attribution-NonCommercial-NoDerivs 3.0 Unported (CC BY-NC-ND 3.0) }}$ 